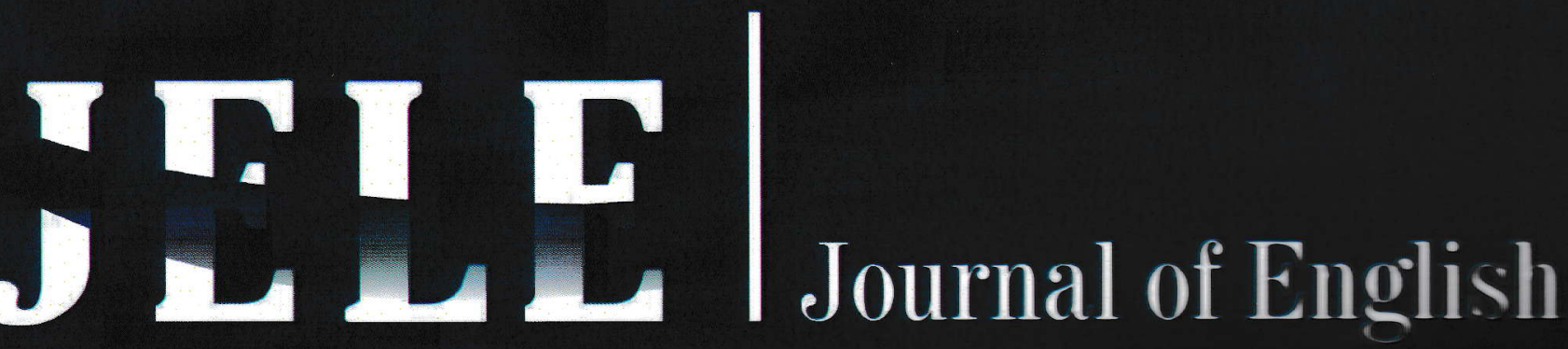 Language and Education
}

English Education Study Program Faculty of Teachers Training and Education Mercu Buana University of Yogyakarta 


\title{
Using English Movies to Enhance Grade XI Students' Speaking Skill (A Classroom Action Research Conducted in SMAN 1 Seyegan, Sleman)
}

\author{
Noor Aeni ${ }^{1}$, Restu Arini ${ }^{2}$ \\ ${ }^{1,2}$ English Education Study Program, Faculty of Teachers Training and Education \\ Mercu Buana University of Yogyakarta \\ ${ }^{1}$ Email : nooraeni7@ymail.com \\ ${ }^{2}$ Email : restuarini@gmail.com
}

\begin{abstract}
This research intended to discover two things, namely the students' interest in learning English by using movies watching media, and the result of the students' speaking skill improvement on cyclical implementations. This research applied Classroom Action Research proposed by Kemmis and McTaggart (2000) with two cycles. Each cycle consisted of a pre-test, treatments, and post-tests. It involved 31 students of XI IPA 3 class in SMAN 1 Seyegan as the research subjects. The result of this research showed that English movies could make the students interested in following the English class. It was proven by the students who became more active to talk in English and did not feel shy or reluctant to share their thoughts. Another result showed that the students' average score was gradually improved from $\mathbf{5 8 . 0 8}$ in the pretest became 65.74 and 74.78 in the first and second post-tests. It can be concluded that English movies is effective to be implemented as an alternative teaching and learning media to teach English speaking skill. Therefore, English teachers are recommended to use English movies to optimize the English learning outcome not only on speaking skill but also other skills.
\end{abstract}

Keywords: Classroom Action Research, English Movies, Improve, Speaking Skill

\section{INTRODUCTION}

Speaking is one of many ways which is used to communicate with each other. To be more specific, there are three purposes of speaking, which are (1) "to inform", (2) "to entertain", and (3) "to persuade", which is why it is considered as a very important activity (Tarigan, 1981:16). By having a good speaking ability, students will be able to deliver their opinion well.
Unfortunately, right now students seem reluctant and shy to speak in front of the public, even only in front of the class. This could not be a good start for them. While they are still studying in school, it is the best time and important for students to develop and increase their speaking ability before graduate and face their wider world.

School and environment would be good places to explore students' 
English competence especially the speaking skill. Yet, when environment does not support the students to explore their English knowledge, then school would be the last choice. Since schools in Indonesia have English as a compulsory subject, it is important for the teachers to have an appropriate method to explore students' English ability especially in speaking. While teachers hold an important role here to guide the students, the best method and media would be much needed.

According to the observation in the English class that the researcher conducted in SMAN 1 Seyegan, it was found that the students who had difficulties in expressing their thoughts. They were shy, less confident, and confused about what to speak. They seem afraid and anxious to speak English in front of the class. The researcher assumed that they probably did not know what and how to express their ideas, thoughts, and feeling in English. It can be caused by some reasons such as difficulty in understanding the material, lack of vocabulary, don't have interest in learning English, and being bored with the learning situation. Moreover, the teaching-learning process in SMAN 1
Seyegan focused on doing exercises on books and supplementary materials provided by the teacher. There was not an appropriate and interesting media that can motivate the students to study English. As the outcome, the students' English skills was low especially in speaking,

Based on the problems above, the researcher intends to enhance students' speaking skill by using a certain learning media. Learning media is a tool that is used to support a teacher in teaching students. In order to have an optimum teaching-learning process, a teacher is expected to have an appropriate learning media that is suitable for the students.

Considering how much an appropriate learning media is needed, the researcher concerns to use movies especially English movies as teachinglearning media in speaking class. "Movies provide both audio and visual materials that help the students understand the language more easily. When watching a film, students not only listen to the characters, but also watch their movements." ( $\mathrm{Hu}, 2006)$. By watching the movies, students have such kind of interaction with the activities in the movies. In the movie 
class they naturally learn to pick up the language from the movie spontaneously. Beside students are basically very familiar with movie which. In short, the use of movie here is not only for entertainment purposes but also for a teaching-learning media to enhance students' spoken English skills.

From the elaboration above, this research is intended to discover two things that are the students' interest in learning English by using movies watching media, and the result of the students' speaking skill improvement on cyclical implementations.

\section{Teaching Speaking}

Speaking is the process of developing and sharing meaning through the use of verbal and nonverbal symbols, in various contexts." Chaney (1998:13) in Kayi (2006).

Classroom speaking activities that can be applied as Brown (2001:271) states are (1) Imitative, a very limited classroom speaking time may be spent generating human's speech production, where, learners practice an intonation contour or try to pinpoint a certain vowel sound.; (2)
Intensive, intensive speaking deals with one step above imitative to include any speaking performance that is designed to practice some phonological or grammatical aspect of language,; (3) Responsive, a good deal of student speech in classroom is responsive: short replies to teacher or students-initiated questions or comments. These replies are usually enough and do not extend into dialogues; (4) Transactional (dialogue), transactional language, carried out of the purpose of conveying or exchanging specific information. It is an extended formof responsive language; (6) Interpersonal (dialogue), interpersonal carried out more for the purpose of maintaining social relationships than for the transmission of facts and information; (7) Extensive (monologue), students are called on to give extended monologues in the form of oral reports, summaries or perhaps short speeches.

\section{English Movies as Learning Media}

According to Pringgawidagda (2002:145), media is a tool used as a medium for delivering teaching materials to the students. In the same 
thought, (Arsyad, 2002:2) defines media as a form medium used by people to deliver or to express the ideas or opinion so they can be received by the receiver. Educational media are used to support the education and can be seen, heard or touched with five senses.

In relation with movies that are used as learning media, $\mathrm{Hu}$ (2006) states that "movies provide both audio and visual materials that help the students understand the language more easily. When watching a film, students not only listen to the characters, but also watch their movements. In addition, the scenes, the props and other aspects make the communication so real that, by watching the film, students seem to almost interact with the activities in the movies. Furthermore, in a film class they tend to learn in a natural way so they pick up the language spontaneously".

In short, movies can be an alternate media supporter in conducting speaking class. Considering by how movies can be very interesting and exciting to encourage students to speak.

\section{Classroom Action Research}

In the era of teaching as research, teacher researchers have adopted the term "action research" to refer to their particular approach to classroom research. So far, action research has proved its suitability to education and become more and more important in education organizations (Hein, 2009:97).

According to Hopkins (1985) a basis for the selection of classroom research by teachers centers around the following criteria: (1) The teacher's primary role is to teach and any research project must not interfere with or disrupt this commitment; (2)The method of data collection should not be too demanding on the teacher's time; (3) The methodology used must be reliable enough to allow teachers to formulate hypotheses confidently and develop strategies applicable to the classroom situation; (4)The teacher should be committed to theresearch problem under study; (5)Teachers must follow ethical procedures when carrying out research; and (6) Classroom research where possible should adopt a perspective where all members of a 
school community build and share a common vision.

This research used Classroom Action Research (CAR) that was proposed by Kemmis and McTaggart (2000) as mentioned in Denzin and Lincoln (2007:276) which presents the CAR cyclical process as follows: (1) planning; (2) acting and observing; (3) reflecting; (4) re-planning; and so on.

\section{METHODS}

This research is categorized as Classroom Action Research (CAR) with the help of a collaborator and students of grade XI SMAN 1 Seyegan. CAR is conducted with the aim of improving the quality of practice learning in the classroom. Meanwhile, the process of CAR involves a spiral of self-reflective cycles of: (a) planning, (b) acting and observing, (c) reflecting, (d)acting and observing, (e) reflecting and so on.

The researcher used some techniques in collecting data as follows: (1) she collected the result of the observation, questionnaire, documentation, and interview that have been done in the first meeting to the last meeting in order to find out the class situation, students need in English class and also to find out their opinion about the English class that they had been following; (2) the researcher collected the results of the speaking tests which included pre-test and post-tests in the form of score. It showed the students' speaking skill before and after the cyclical implementation.

This research used descriptive qualitative data which covered the descriptions of the students' speaking skill before and after they got treatments and it was also supported by quantitative data. There were two stages that the researcher did in this section, the first one was data analysis and the second one was assessing.

The data analysis consists of four components: (1) Data Collection. They were in the form of raw data which were taken from the research such as questionnaire, documentation, interview and test results; (2) Data Reduction. After the data were all collected, it was needed to classify all the data by making summary; (3) Data Display. After the researcher classified the data the next step was displaying the data in the form of description so that it can totally be more 
understandable and also can form the conclusion to do the next analysis; (4) Conclusion: drawing/verification. The collected result of the research and the conclusion then had to be verified by checking them towards the data reduction and the data display so that the conclusion that was made can be used as the credible report of the research.

\section{FINDINGS AND DISCUSSION}

\section{The Students' Interest in Learning} English by Using Movies Watching Media

Before the researcher holds a pre-test, she first interviewed the English teacher of XI IPA 3, the class that was being researched. The interview was to find out the running English class and students' condition. The questions that were asked cover the teacher's opinion about the students' interest in English subject, the media that were used to support the teaching and learning process, the teacher's opinion about the students' English skill competences, especially in speaking skill competence. Based on the interview with the teacher, many students liked the English subject. Their English competences were average. Meanwhile for the speaking skill, the teacher said the students have less competence on it.

In showing their speaking performance, most of the students still hesitated in expressing their thoughts. They also directly asked their friends when they did not know about what to talk next. Most students spent less thantwo minutes in performing their speaking performance. The class situation was quieter comparing to when they were still preparing their speaking performance.

While conducting the pre-test, the researcher was also having an observation towards the class situation and the students' behaviors. Based on the observation, students seemed quiet and unwilling to speak. Some students that seemed uninterested to the lesson tended to read other books, having chats with their friends or just quiet and playing the stuff around them. Some students also did not pay attention to their friends who were performing. Students did not enthusiastic in following the English class since, the researcher found out already, based on the observation conducted in before the 
implementation of the pre-test and the cycles, there was not interesting media used in the teaching and learning process.

\section{The Implementation of Cycle 1}

Having finished with the pretest, the researcher then conducted the first cycle in the next meeting. By having some observations during the cycle implementation, the researcher could find the students' interest towards the English learning. In the first meeting of the first cycle, the researcher played a movie entitled "Mega Mind." The students became excited. All of the students paid attention on the screen in front of them. After the movie was finished, the students were asked to have a discussion in groups. The class became livelier, all the students tried to speak English as much as they can although often they mixed it with Bahasa. In the discussion section, students would directly ask the researcher and did not feel reluctant when they have questions.

On the second day of the first cycle, the researcher conducted posttest 1. It was aimed to find out the students' speaking improvement. The students had already known that they would have such kind of speaking performance in the second day of the first cycle. At first, the students pretended to not know about what they had to do in that day that was speaking performance. A student said "Apa to Mbak?" (What are you talking about?) and other student said "Watching movie to Mbak?" (Are not we going to watch a movie again?) Seeing this situation, the researcher assumed that the students were not ready for their speaking performance. She then decided to give the students several minutes to discuss the movie with their partner using English, many times they mixed it with Bahasa. The class started to be noisy. After finishing the discussion, the students were called one-by-one to show their speaking performance. Some minutes have passed but no one of them was willing to do so. Even though the researcher only gave each of them two minutes to talk, many students still reluctant to speak. They preferred perform it while sitting than perform it in front of the class. The researcher then told the students that not only their speaking contents that would be assessed but also their performance. 
After several minutes, some students who were confident to speak in front of the class indirectly influenced other students who were shy to get up and do their speaking performance. Many students practiced their oral performance by themselves while watching their friends' performance.

\section{The Implementation of Cycle 2}

After conducting the first cycle, it was found that the students' speaking skill still needed to be improved more, so that the researcher conducted the second cycle. In the first meeting of the second cycle, the researcher reviewed the speaking material given in the first meeting of cycle 1 . In this meeting, the researcher was also having a discussion with the students related to the students' speaking performance in the previous meeting. In the discussion session, the students were confident and comfortable in delivering their thoughts and opinion.

Having finished with the discussion, the researcher played the second movie entitled "Mars needs Mom."This movie was chosen by considering the movie story where it is related to life story about parents- children and covered with some fictional story which made the students interested. This movie was also chosen since it has the same difficulty story level to be understood by the students with the previous movie. Again the students were excited and focused on the movie. The researcher found that the students become more and more excited when it comes to movies. The movie that was played in the second cycle was actually has more than an hour in length. But the researcher played the first twenty minutes only since she had a limited time.

After the movie has finished, the students were given several minutes to discuss the movie with their partners. This time the researcher also delivered similar worksheets to the students. They had to discuss the tasks with their partners. During the discussion session, the researcher found that the students became more active to speak in English. They did not hesitate to deliver their opinion and thoughts in English. They were more comfortable to speak in English with their friends. Most students were not afraid to make mistakes while speaking. In this meeting almost all 
students showed their confidence in speaking in English. Even though their friends would laugh because of the English grammatical errors that they made or they found out something funny during their speech, they did not show such kind of weak-hearted and just continuing their speech.

In this meeting the researcher did need to call the students' names one-by-one to perform. The students would directly come in front of the class one-by-one and showed their speaking performance. They instantly went to the front of the class whenever their friends finished with their performance. It shows that their confident increased compared to the previous meetings. The students eager to show their speaking performance better. Some students who spoke less before became more active to speak and did not feel burden anymore.

In doing the performance, most of the students were more relaxed and enjoyed it. Sometimes they were joking around while performing with their friends who were practicing. Many students showed their speaking performance for more than two minutes. Sometime the researcher had to stop them because they have far passed the given time. Most of them showed their speaking performance for more than two minutes. In the previous post-test, the researcher spent for about 70 minutes in assessing the students, but in the post-test 2the researcher spent about 80 minutes.

As the researcher observed, the students seemed to have more confidence in delivering their thoughts. Even though there were still few students who were shy and afraid to deliver their thoughts, most of them were no longer feeling shy or reluctant to speak in English.

\section{The Students' Speaking Skill} Improvement Result on Cyclical Implementations.

\section{The Result of Pre-Test}

In the pre-test stage, the students were asked one by one to retell the English movies that they have watched. The pre-test result discovered that the students' speaking skill performance was considered as low with their average score 58.07.

Here is the result of the pretest: 
Table 1. The Students' Pre-Test Average Score.

\begin{tabular}{clcc}
\hline No. & \multicolumn{1}{c}{ Aspects } & Scores & Categories \\
\hline 1 & Pronunciation & 59.19 & Poor \\
2 & Fluency & 57.66 & Poor \\
3 & Topic Mastery & 58.62 & Poor \\
4 & Performance & 57.74 & Poor \\
5 & Vocabulary & 57.17 & Poor \\
\hline \multicolumn{2}{r}{ The average scores } & 58.07 & \\
\hline
\end{tabular}

Category: 10-39 = Very Poor

$$
\begin{aligned}
& 40-60=\text { Poor } \\
& 61-70=\text { Average } \\
& 71-80=\text { Good } \\
& 81-100=\text { Very Good }
\end{aligned}
$$

The data in the table above indicates that the students' speaking skill is categorized as poor. The average score of each speaking aspect were under 60 .

The pronunciation aspect deals with the students' sounds of words, pronunciation of sentences, and also the right intonations and stress. Based on the pre-test result, the average score was 58.07 which was categorized as poor and need to be improved. Furthermore the fluency covers how fluent the students speak, smoothly without hesitation, appropriate pause, and repeating words/lines. Topic mastery deals with the students' understanding related to the discussed topics. Performance deals with the students' behavior during their speaking tests, whether they are confident, shy, hesitate, or enthusiast. And the last is vocabulary which covers the students' ability in choosing appropriate words and how to solve the problems when he/she cannot find suitable words by explaining around the world.

\section{The Result of Cycle 1}

At the end of the first cycle, the researcher held a post-test which resulted the students' average score as the researcher called as post-test 1 . Compared to the result of the pre-test average score, the result of post-test 1 showed some score improvements in students' speaking skill.

To get clear differences between the average pre-test score and the post-test 1 average score, the researcher compared the two post-test 
results along with the amount of the students' speaking skill. Here is the improvement for each aspect. It was improvement score: found that there were improvements in

Table 2. The Average Improvement Score between Pre-Test and Post-Test 1

\begin{tabular}{clccc}
\hline No. & \multicolumn{1}{c}{ Aspects } & $\begin{array}{c}\text { Pre-Test } \\
\text { Scores }\end{array}$ & $\begin{array}{c}\text { Post-Test 1 } \\
\text { Scores }\end{array}$ & Improvements \\
\hline 1. & Pronunciation & 59.19 & 64.88 & 5.69 \\
2. & Fluency & 57.66 & 64.75 & 7.09 \\
3. & Topic Mastery & 58.62 & 66.61 & 7.99 \\
4. & Performance & 57.74 & 66.69 & 8.95 \\
5. & Vocabulary & 57.17 & 65.8 & 8.63 \\
\hline Average & \multicolumn{3}{c}{7.67} \\
\hline
\end{tabular}

Based on the table above, it can be concluded that students' speaking performance was improved in each aspect, especially in performance aspect that showed the highest improvement. It was needed to hold the second post-test since the students had not reach the minimum score.

\section{The Result of Cycle 2}

After conducting cycle 1 which involved post-test 1 , the researcher then hold post-test 2 in the end of cycle 2 . In this cycle, the average score was gotten. To get clear differences between the post-test laverage score and the post-test 2 average score, the researcher also displays the comparison between the two post-test along with the amount of the improvement scores. Here is the result:

Table 3. The Average Improvement Score between Post-Test 1 and Post-Test 2

\begin{tabular}{llccc}
\hline No. & \multicolumn{1}{c}{ Aspects } & $\begin{array}{c}\text { Post-Test 1 } \\
\text { Scores }\end{array}$ & $\begin{array}{c}\text { Post-Test 2 } \\
\text { Scores }\end{array}$ & Improvements \\
\hline 1. & Pronunciation & 64.88 & 72.5 & 7.62 \\
2. & Fluency & 64.75 & 75.16 & 10.41 \\
3. & Topic Mastery & 66.61 & 74.83 & 8.22 \\
4. $\quad$ Performance & 66.69 & 76.61 & 9.92 \\
5. $\quad$ Vocabulary & 65.8 & 74.83 & 9.03 \\
\hline \multicolumn{2}{l}{ Average } & & & 9.04 \\
\hline
\end{tabular}


Based on shown the table above, it can be concluded that students' speaking skill was improved in each aspect where again this time the performance aspect got the highest improvement. It can be seen that the students' speaking skill was categorized as low before the research was conducted. It gradually improved after the two cycles was conducted.

Students' average score in speaking skill performance has improved gradually after several treatments using English movies as media. As it was described before where the students get more excited and enjoy the speaking class. It was also showed from the improvements in the average scores of each aspect. Here is the summary of the students' average score from pre-test, post-test 1 , and post-test 2 along with the calculated improvement scores:

Table 4. The Improvement Score Total

\begin{tabular}{llcc}
\hline No. & \multicolumn{1}{c}{$\begin{array}{c}\text { CAR } \\
\text { Implementation }\end{array}$} & Scores & Improvement Scores \\
\hline 1. & - Pre-Test & $0-58.07$ & - \\
2. & Pre-Test - Post-Test 1 & $58.07-65.74$ & 7.04 \\
3. Post-Test 1 - Post- & $65.74-74.78$ & 9.06 \\
\hline & & \\
\hline & Test 2 & 16.1 \\
\hline
\end{tabular}

If it is calculated, the total of the improvement scores is 16.1.Considering the result above, it can be concluded that English movies can improve the grade XI students' speaking skill.

\section{CONCLUSION}

This research has two objectives. Tthe first one is to find out the grade XI students' interest in learning English through movies watching media. Before conducting two cyclical implementations, most of the students were uninterested in the English learning that they had been following. The used of teaching and learning media in English class were not interesting enough for the students since the teacher was only focused on the textbook, $L K S$, and LCD which 
only displayed materials. Being taught by using movies as media in classroom learning, the students became more interested and excited in following the English class. After conducting the two cycles, the students showed excitement in the English learning. The English movies could make the students interested in following the English class. The students became more active to talk in English, they without doubt responded to the teachers' questions and instructions in English. Meanwhile, the second objective of this research was to find out the improvement of the grade XI students' speaking skill by using movies. Based on the result of the pre-test and the two cycles, students showed some improvements in each speaking aspect in their speaking performances. The students' average score in Pre-Test was 58.07 which became 65.75 in Cycle 1 and the average score in the cycle 2 was 74.78. By considering the improved scores that the students showed, it can be concluded that after the English movies were applied as media in English learning, the students' speaking performance were gradually enhanced.

\section{REFERENCES}

Arsyad, Azhar. (2002). Media Pembelajaran. Jakarta: Raja Grafindo Persada.

Brown, H. D. (2001). Teaching by Principles: An Interactive Approach to Language Pedagogy. New York: Wesley Longman.

Denzin, N.K. \& Lincoln, Y.S. (2012).The Sage Handbook of Qualitative Inquiry, $4^{\text {th }} \mathrm{Ed}$. CA: Sage Publication.

D. Hopkins. (1985). A Teacher's Guide to Classroom Research. Philadelphia: Open University Press.

Hien, Tran Thi Thu. (2009). Why is Action Research Suitable for Education? VNU Journal of Science, Foreign Language. (http://tapachi.vnu.edu.vn/nn_ 2_09/b4.pdf, accessed on June 15, 2014)

Hu, S. F. (2006). On teaching nonEnglish Majors Listening and 
Journal of English Language and Education

Vol 1. No. 1, June 2015

Speaking through Videos.

China English Language

Education Association

Journal, 29(2), 42-48.

Kayi, Hayriye. (2006). Teaching

Sepaking: Activities to

Promote Speaking in a

Second Language. The

Internet TESL Journal,

Vol.XII, No. 11.

Priggawidagda, Suwarna. (2002).

Strategi Penguasaan

Berbahasa. Yogyakarta:

Adicita Karya Nusa.

Tarigan, Henri Guntur. (1981).

Berbicara Sebagai Salah Satu

Aspek Keterampilan

Berbahasa. Bandung:

Angkasa. 


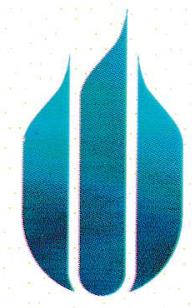

U N I VER S I TAS

MERCU BUANA

Y O G Y A K A R T A

ENGLISH EDUCATION STUDY PROGRAM

Faculty of Teachers Training and Education

Mercu Buana University of Yogyakarta

J. Wates Km. 10 Yogyakarta 55753 | jurnal.umby@gmail.com

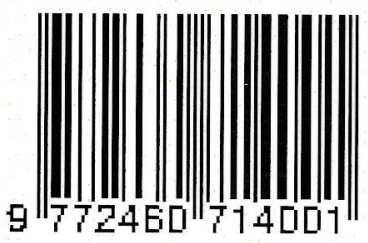

